VI.-Alien Oligochrts in England.

By The Rev. Hilderic Friend, F.R.M.S.

(Read Jamuary 19th, 1916.)

Figs. 1-6.

Kerria rubra sp.n.

Whenever plants introduced from abroad have soil attached to their roots there is the possibility that young worms or cocoons may be present. Under suitable conditions these may develop, and in time become prolific. It is reasonable to suppose that in many cases the young die, and the cocoons fail to yield up living forms ; but we have a number of records, based on more or less careful observation, to show that not a few alien Oligochæts have during recent years found their way to this country. Kew is naturally the place where the largest number of aliens have been found, and both Beddard and myself have placed on record at various times the results of our work on the Annelids of Kew Gardens. Elsewhere the species which have been most frequently reported are Pheretima (Perichata) indica Horst, which is, as

\title{
EXPLANATION OF FIGURES.
}

The Roman numerals refer to the number of the segment.

Fig. 1.-Transverse section through segment 7 , showing the arrangement of the setæ, thickened septa, glands, œsophagus, and nephridia.

"2.-Longitudinal vertical section through segments 8-15, showing gonads, œsophageal glands, girdle, and extended intestine.

, 3.-Longitudinal section through spermathecæ.

" 4.-Transverse section through segment 9, with glands opening into the œsophagus.

, 5.-Longitudinal section through the anterior portion, to illustrate the shape and position of the brain.

"6.-Longitudinal section through girdle segments, with prostates and male pore.

Abbreviations :- at. attachment of brain; b.c. buccal cavity; $b r$. brain; b.v. blood-vessel ; $d$. dorsum ; d.v. dorsal vessel ; gir. girdle : int. intestine; int.e. intestinal enlargement ; l.s. lateral setæ ; $m$. muscle; m.p. male pore ; n.c. nervecord; neph. nephridium; as. œsophagus; as.gl. œsophageal gland; o.f. funnel of oviduct; os. ovisac; ov. ovary; $p h$. pharynx; p.p. prostate pore; $p r$. prostomium; ps. prostates; sep. septum; sep.gl. septal gland; s.f. sperm-funnel; sp.s. sperm-sac; spth. spermatheca; $t$. testis; $v$. venter; v.s. ventral setæ; v.v. ventral vessel. 
Michaelsen remarks, "durch Verschleppung nahezu kosmopolitisch," and Microscolex phosphoreus (Ant. Dugès), also a "vielfach verschleppte Art." It is probable that if the various specimens hitherto reported under these two headings were subjected to a critical examination, it would be found that several species have been recorded under one name.

My reason for this statement is based on the fact that my most recent researches show that our alien Annelid fauna is very little known. From many parts of the country collections have reached me which show that a good deal of work remains to be done, and if a systematic examination of all the worms found at Kew, Chelsea, Oxford, Cambridge, Edinburgh, as well as in those districts in which foreign bulbs and other plants are grown under glass or in market gardens, we should add greatly to our knowledge of an interesting and useful subject. In support of this statement, I propose to submit details of a new species of Oligochæt worm found in this country. It is of more than ordinary interest because it is the first time that any representative of the genus has been found in Europe.

\section{I.-Historical Survey.}

The genus Kerria was created by Beddard in 1892 (1).* " Mr. J. Graham Kerr," he writes, "who accompanied the Pilcomayo Expedition in 1890, has kindly given me a number of small Oligochæta which he collected in the upper reaches of that river. . . The water where they were met with was exceedingly salt and bitter, but contained a number of other animals, notably a few decapod Crustaceans. So far as I am aware, no Oligochæte of any kind has ever been described from a locality like the present, except a species of Pachydrilus, referred to by Semper as oceurring in the brine-springs of Kissingen in Germany. Salt water is not, however, entirely inimical to the existence of Oligochæta, for there are a few species known from the sea-shore." After describing the worm, the writer concludes that "it will be necessary to institute a separate genus for this Acanthodriloid worm from the Pilcomayo, and I propose to call it Kerria, after Mr. Graham Kerr, with the specific name halophila."

Perhaps no one has done more to extend our knowledge of the genus than Rosa, whose various contributions to the Bulletins of the Turin Museum (') may be consulted with advantage. We owe to him the discovery of some half-dozen species of Kerria, in or about 1895, while Eisen (3) and Michaelsen (5) have still further extended our knowledge of the genus. Beddard's Monograph (2) shows that four species of Kerria had been recognized in

* The figures within brackets refer to the Bibliography at the end of the paper. 
1895. Five years later Michaelsen (6) tabulated no fewer than eleven, and two other species have since been added to the list. The present form, therefore, brings the known species of Kerria to fourteen.

\section{II.-Distribution.}

As already stated, the first species, Kerria halophila Bedd., which forms the type, was found in salt water in the Pilcomayo. Later research has added many South American, West Indian, and Californian localities to the list. Mention may be made of Buenos Ayres, Uruguay, Southern Brazil, Paraguay, Valparaiso, Juan Fernandez, and San José del Cabo. The species are not all found in salt or brackish water, but flourish also in fresh water and in soft ooze or mud. Michaelsen summarizes the matter thus :"Terrestrisch, im Süsswasser und in salzhaltigem Wasser. Subtropisches Süd-Amerika und Nieder-Californien." It is, therefore, clear that when the genus is found represented in England it cannot well be indigenous.

\section{III.-Generic Characters.}

Though Beddard did not summarize the generic characters in his original description, he supplied a definition in his Monograph, which reads as follows :-

"Setæ paired, present on all the segments of the body except seta 2 on segments XVII and XIX of some species. No dorsal pores. Nephridia paired. One pair of testes in x. Spermiducal glands lined by a single layer of cells; no penial setæ. Spermathecæ with or without diverticula."

The difficulty with this definition is that it leaves one in doubt about the allied genera, as the author himself realized. "Very little is wanted," he writes, "to convert the (type) species into an Ocnerodrilus," while "it undoubtedly agrees in all those points which are made use of to define the genus Acanthodrilus. . . If it were not for the position of the calciferous (œsophageal) glands, all the resemblances between this worm (the type of the genus Kerria) and Ocnerodrilus might fairly be set down to a convergence due simply to degeneration."

The researches of Rosa made it possible to enlarge and define the generic characters with greater exactitude, and Michaelsen $(6)$ was able in 1900 to give the following as the definition of Kerria :-

"Männliche Poren am 18 Segm.; Prostataporen 2 Paar, am 17 und 19 Segm.; Samentaschenporen meist 2 Paar, auf Intersegmtf. $7 / 8$ und $8 / 9$, selten die vorderen fehlend, 1 Muskelmagen im 7 Segm. oder keiner; 1 Paar seitliche Esophagealtaschen im April 19th, 1916 
9 Segm., meist einfach, selten mit nephridialen (?) Elementen verbunden. 2 Paar Prostaten (selten verdoppelt) münden getrennt von den Samenleitern aus; 1 Paar Hoden frei im 10 Segm. (Hoden bei wenigen Arten nicht beobachtet). Samentaschen meist ohne Divertikel, selten mit Aussackungen am distalen Ende der Ampulle (Divertikel ?)."

Possibly further research will show the need of a modification of this definition. As at present understood, we find the genus including species which show widely divergent characters, such as the presence or absence of a gizzard, diverticula to spermathecæ, pigmentation, etc. The spermathecæ may be either one or two pairs, and the two pairs of prostates may be doubled. On the other hand, in some cases the gizzard is rudimentary, and so acts as a bridge between the species which possess one and those which are destitute of that organ; and the definition as set out by Michaelsen makes it impossible to remain in doubt whether or not a given species should be called Acanthodrilus, Ocnerodrilus or Kerria, as was the case in earlier days. Indeed, Ocnerodrilus has now been raised to a sub-family of which Kerria is one of the genera.

\section{IV.-Description of Kerria rubra sp. n.}

Two years ago, while on a visit to Oxford, I found in the Lily House at the Botanic Garden a species of worm which I had not previously seen. It lived in the oozy mud which surrounded the plants on one side of the tank, and was accomparied by Pheretima (indica?). Unfortunately, it proved so tender and susceptible to adverse influences that when I reached home it had perished, and the relics were beyond recognition. I had, however, assured myself that, whatever the worm might be, it had never been recorded for this country, even as an alien. I therefore availed myself of the earliest opportunity which presented itself of again visiting the Garden, in the hope of obtaining further material. Though the creature was not abundant, I had the good fortune on June 21st, 1915, to secure two adults, and it is upon these that the following observations are based.

External Characters.-Kerria rubra is a very slender, delicate worm, extending while alive to two or three inches in length, but contracting to about $1 \frac{1}{2} \mathrm{in}$. in alcohol. It does not exceed $2 \mathrm{~mm}$. in its greatest diameter, which is in the region of the girdle. The colour is red in the living worm, but the pigment disappears when it is preserved, and the region behind the girdle is so transparent as to admit of the nephridia being readily seen as large white convoluted bodies. It closely resembles a slender specimen of Helodrilus oculatus Hoffm.

The number of segments is about ninety; the setæ number eight, 
and are arranged in four pairs, which are disposed as shown in the illustration (fig. 1, l.s., v.s.). The girdle extends from the 13 th to the 20th segment, and a pocket lens reveals very slight

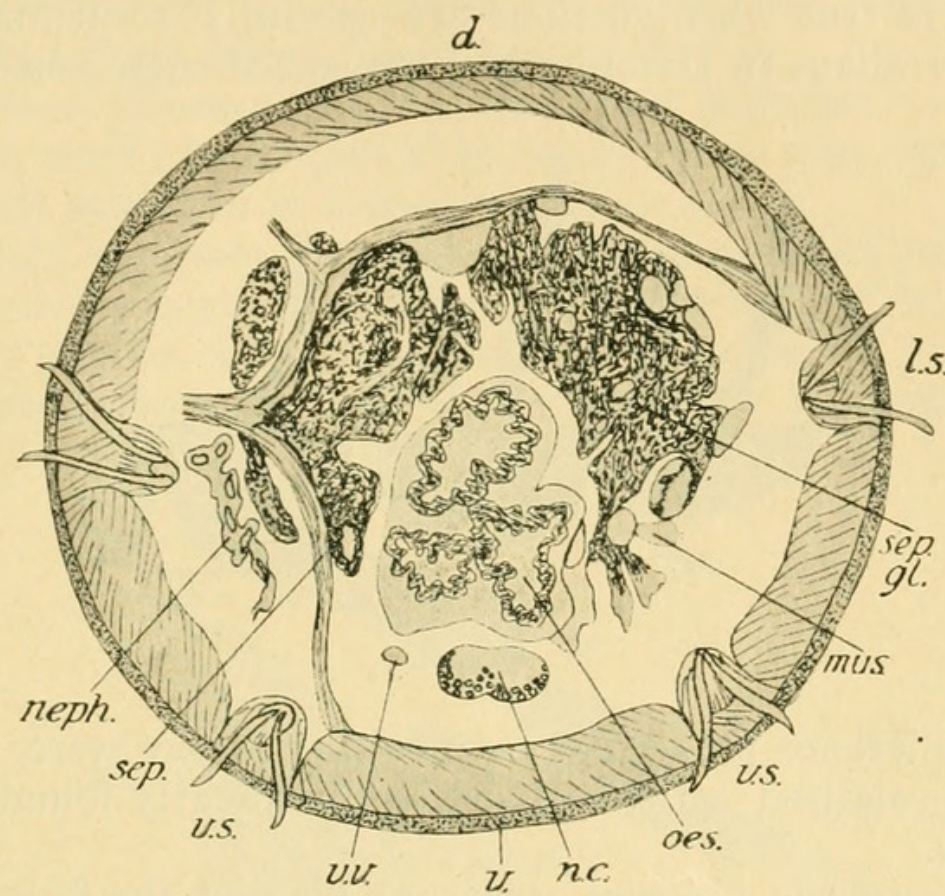

FIG. 1.

prominences on segments $17,18,19$ ventrally. Sections show that these are related to the prostates and male pore. The girdle is saddle-shaped, but appears to cover a good part of the ventral

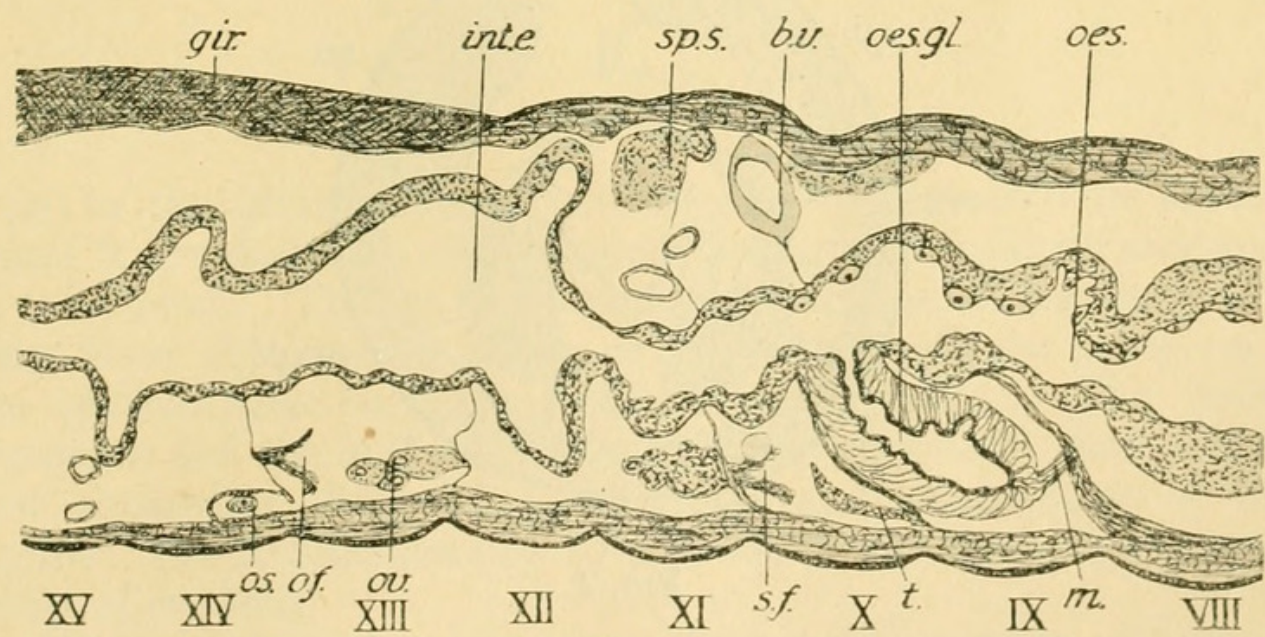

FIG. 2.

surface in a perfect adult. The illustration (fig. 2, gir.), shows it developed on the dorsal surface only. The shape of the head was not observed in the living worm. The anus is terminal. 
Negative Characters.-In studying this species it soon becomes apparent that certain familiar characteristics of many Annelids are wanting. If one is examining the adult worm, whether living or preserved, it is impossible to detect the presence of dorsal pores. The same is true when sections are carefully scrutinized. As I found other aliens in Oxford which possessed such pores, this first

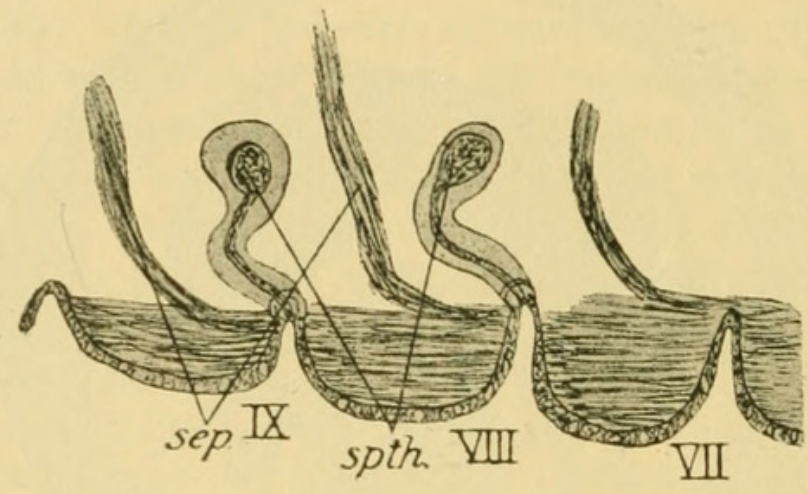

FIG. 3.

point of difference proved very arresting. There were, further, no signs of specialized setæ, such as are frequently found in foreign Oligochæts.

Coming to the internal structure, we find the following noteworthy negative characters :-

There are no diverticula to the spermathecæ; these are not

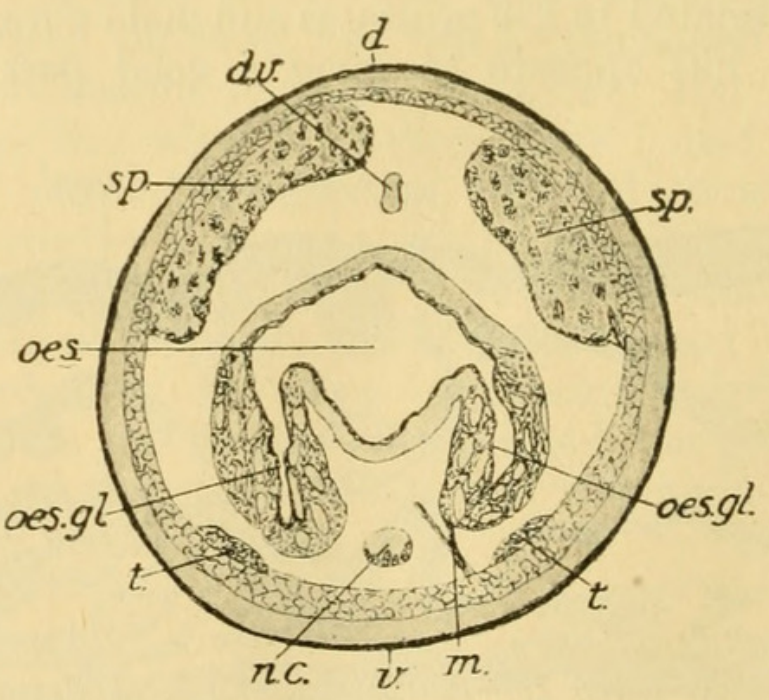

FIG. 4.

attached to the intestine, nor do glands exist at the opening. The worm is devoid of peptonephridia (salivary glands), and it has no cœlomic corpuscles or chloragogen cells. There is no tongue or taste organ, nor do prostrate papillæ present themselves in any noticeable fashion on segments 17 and 19. Calciferous glands are 
wanting, their place being taken by a pair of ventrally-disposed cesophageal glands. This species, moreover, possesses no gizzard.

A further marked peculiarity is the absence of nephridia from the 11th and 14th segments. Beddard says of the type, that "The nephridia are present in the genital segments ; the posterior set are invested by a thick layer of peritoneal cells."

Altogether, the negative characters are important and instructive, and it would be helpful if in future those who described new species drew attention to these points.

Internal Characters.-As the sexual organs are of prime importance, it will be well if we study them first. It will then be possible to pass on to the other features of interest.

The spermathecx are paired, and open (in harmony with the

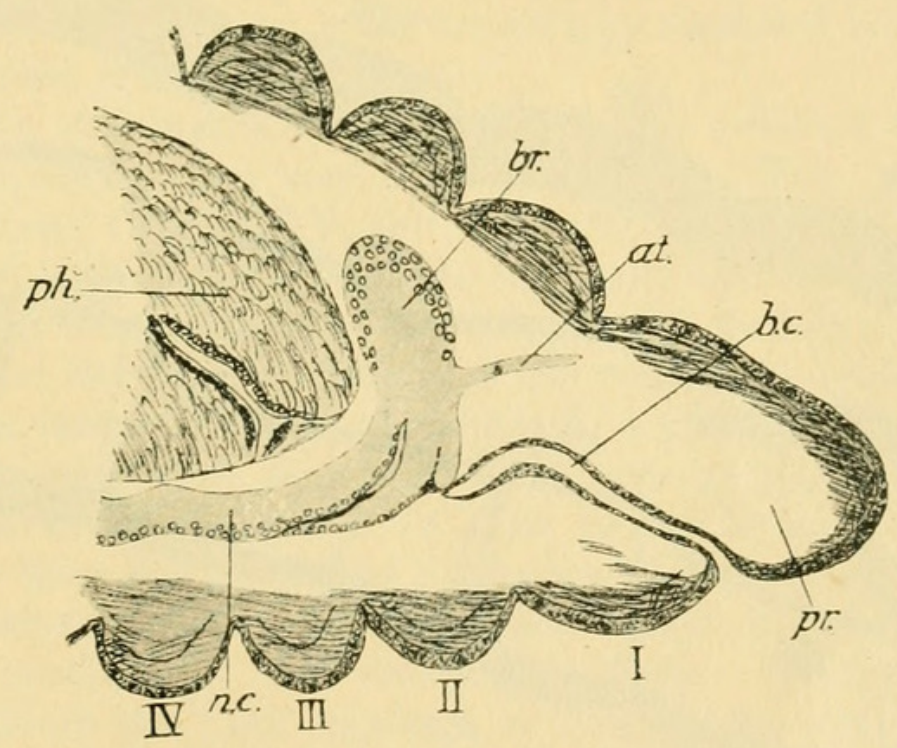

FIG. 5.

type) in the intersegments $7 / 8$ and $8 / 9$. They occur in segments 8 and 9 , are destitute of diverticula and glands, and lie unattached in the cœlom. Though the worms were found in England, it was quite clear that the processes of reproduction were going on, for the spermathecæ were packed with spermatozoa. The twist of segments and the angle at which the sections were cut made it at first somewhat difficult to determine the exact shape of these organs. The illustration (fig. 3) is based on the study of a complete series of sections.

The spermiducal orifices are on the ventral surface of segments 17 and 19, the papillæ being inconspicuous. As is the case with the type, so here " the glandular tube is lined by a single layer only of cells." In this respect the genus agrees with typical Ocnerodrilus. The tubes or ducts go back at least as far as segment 21 , beyond which my longitudinal sections do not carry me. 
The diameter of the lumen does not exceed one-fifth that of the duct. The glandless portion is short, and may be said to equal in length the thickness of the girdle (fig. 6, p.p.) on the venter.

One pair of testes is found in the tenth segment (fig. 2, t.) attached to the posterior side of septum $9 / 10$. In the same segment, attached to the anterior portion of septum 10/11, is a pair of funnels. Two pairs of sperm-sacs occupy the 10th and 11th segments, but the anterior pair pushes forward (fig. 2, sp.s.) into segment 9 . The position of the testes and sperm-sacs agrees with that of the type.

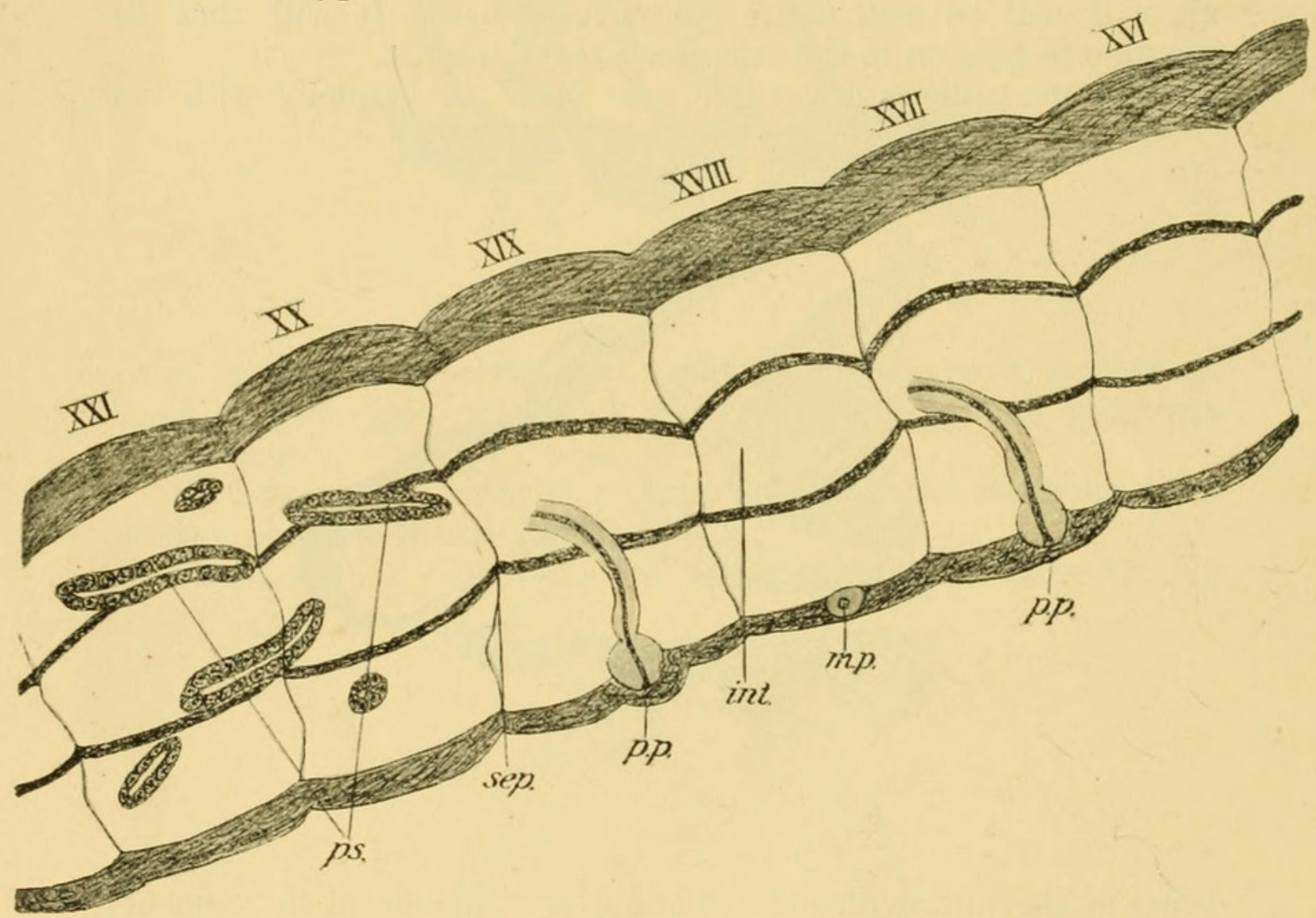

FIg. 6.

The ovaries are seen (fig. $2, o v$.) to be situated in segment 13 , and funnels or oviducts are attached to the anterior of septum 13/14, while ovisacs are found in segment 14 . In the type described by Beddard no ovisacs occurred.

The male pores are on the ventral surface of segment 18, but I have been unable to trace the duct from segment 10 . The pores do not lie in the same plane as those of the prostates.

Kerria rubra possesses no peptonephridia, or salivary glands. The ordinary nephridia commence in the 7 th segment, and are found in all the remaining segments except 11 and 14 . In the 
worm preserved in alcohol they can be seen behind the girdle as a pair of large white convoluted bodies. In section some portions have an appearance which recalls the "flames" in the nephridia of Enchytræids.

The alimentary system presents several points of interest. The intestine widens greatly in segment 12 (fig. 2, int.e.). Attached to the ventral side of the oesophagus in the 9th segment is a pair of glands which in structure exactly resemble those of Henlea fragilis Friend (4). The illustrations (figs. 2 and 4) show them to be securely attached to the posterior surface of the strengthened intersegmental septum 8/9. These organs were known to Beddard as "calciferous pouches," but Michaelsen designates them "Chylustaschen." They are pear-shaped, and open directly into the esophagus. There is no trace of the "nephridial element" here, which has been doubtfully recorded for some other species. There is also no gizzard.

The septa, or mesenteries, in some of the anterior segments, as is very frequently the case, are thickened. This applies in a marked degree to $6 / 7,7 / 8$, and $8 / 9$, and in a lesser measure to $4 / 5,5 / 6$, and $9 / 10$. Some of these septa are displaced, being thrust back so much that later septa become greatly crowded. The septal glands extend between the 4th and 8th segments, their maximum deveiopment being dorsal in segments 5, 6 (fig. 1, sep.gl.).

The nervous system does not require any special attention. The shape of the brain could not be seen in the living worm, but its contour has been reconstructed by means of a series of longitudinal vertical sections (fig. 5). I have not found it possible to give a detailed account of the vascular system. Sections, however, seem to indicate the 11th segment as the one in which the bloodvessels assume their largest development (fig. $2, b . v$.).

\section{V.-Relative Position of Kerria rubra.}

The various species of Kerria may be arranged according as they have or have not diverticula to the spermathecæ, double or single prostates, copulation papillæ, one or two pairs of spermathecæ, pigment in the body-wall, and a rudimentary or fullydeveloped gizzard, as against the absence of a gizzard, and the existence or otherwise of ovisacs, as well as by sundry other features.

As we have seen, Kerria rubra possesses no diverticula to the two pairs of spermathecæ. The prostates are not doubled, and there is no gizzard, but an ovisac is present, and the creature is red. If, now, we tabulate the characters of those species of Kerria which show these peculiarities, we shall be able to judge which of 
them our present species most nearly resembles. To take the most important organs first:-

Two pairs of spermathecæ are found in the majority of species, opening in the intersegments $7 / 8,8 / 9$. One pair only occurs in K. macdonaldi Eisen. Copulation papillæ exist in K. papillifera Rosa, $K$. stagnalis (Kimb.), and some others. A small or rudimentary gizzard (Muskelmagen) is found in $K$. garmani Rosa, $K$. saltensis Bedd., $K$. rosæ Bedd., $K$. macdonaldi Eisen, and $K$. eiseniana Rosa; it exists in $K$. kükenthali Mich., and is well developed in $K$. asunscionis Rosa, $K$. halophila Bedd., K. subandina, while none is found in K. stagnalis (Kimb.), K. papillifera Rosa, and $K$. rubra Friend. But $K$. stagnalis and $K$. papillifera have muscular papillæ on segments 17 and 19 where the prostates open, whereas these are usually wanting in other species, including rubra.

Emphasis is laid by some systematists on the position of the external pore of the spermathecæ. If we name the setæ from the ventral to the dorsal $a, b, c, d$, then the spermathecæ may be said to open in a line with $a, b, c$ or $d$, or between any two of these. Thus the spermathecæ of $K$. subandina open midway between setæ $c$ and $d$, whereas in $K$.halophila (Beddard's type species) the opening is in the line $a b$. In this respect $K$. rubra is unlike the foregoing, but approaches $K$. macdonaldi and $K$. eiseniana, whose spermathecæ open immediately below $c$, but in each of these the spermathecæ differ from those of $K$. rubra.

K. rubra, therefore, occupies a position of its own, and it is on this account, perhaps unfortunate, that we have no means of knowing its original home. It may be possible to assign a place to $K$. rubra by following Michaelsen's classification.

1 Prostate opening through muscular papillæ . . . . . 2

1 Opening of prostate simple . .

2 Girdle forming a complete ring . . .

$2\{$ Girdle saddle-shaped . .

( Prostate doubled

3 Prostate single

4 Spermathecal pores in line $a b$

( Spermathecal pores in line $c d$

5 Girdle ring-shaped, 14-19 segments .

5 Girdle weak ventrally, 13-20 segments

6 Spermathecæ with outgrowths

Spermathecæ bottle-shaped

1. K. stagnalis

2. K. papillifera

3. K. zonalis

$. \quad . \quad 4$

.$\quad .5$

$\cdot \cdot 6$

4. K. halophila

5. K. asunscionis

- 6. K. macdonaldi

- 7. K. rubra

In the three last species the girdle is on segments $13-20$, and the spermathecæ of $K$. asunscionis resemble those of $K$. rubra. But while in K. rubra the gizzard is absolutely wanting, and in $K$. macdonaldi at best rudimentary, in $K$. asunscionis it is fully developed. 
Alien Oligochrts in England. By Rev. H. Friend.

We may tabulate the results thus:-

\begin{tabular}{|c|c|c|c|c|c|}
\hline \multicolumn{3}{|c|}{ ORGaNs. } & Asunscionis. & Macdonaldi. & Rubra. \\
\hline \multicolumn{3}{|c|}{$\begin{array}{l}\text { Spermathecal open- } \\
\text { ing } .\end{array}$} & In line $a b$ & In line $c d$ & In line $c d$ \\
\hline Gizzard & . & $\cdot$ & Present & Rudimentary & Absent \\
\hline Spermathec & & $\cdot$ & Pear-shaped & With outgrowths & $\left\{\begin{array}{c}\text { Pear or bottle- } \\
\text { shaped }\end{array}\right.$ \\
\hline Girdle . & $\cdot$ & . & $\left\{\begin{array}{c}\text { Saddle-formed, } \\
13-20 \text { segm. }\end{array}\right.$ & $\begin{array}{l}\text { Saddle-formed, } \\
13-20 \text { segm. }\end{array}$ & $\begin{array}{l}\text { Saddle-formed, } \\
13-20 \text { segm. }\end{array}$ \\
\hline Prostrate & . & . & About $1 \mathrm{~mm}$. long & Thin and short & $\left\{\begin{array}{l}\text { Extending back to } \\
21 \text { st segm. at least }\end{array}\right.$ \\
\hline
\end{tabular}

\section{BIBLIOGRAPHY.}

1. 1892. BEDdARD-P.Z.S., pp. 355-61.

2. 1895. " Monograph of the Order Oligochæta.

3. 1893. Ersen-Pro. Cal. Acad., ser. 2, iii. p. 294, et seq.

4. 1915. Friend-Annals of Applied Biology.

5. 1908. Michaelsen-Zool. Jahrb., Suppl. 11, Heft. i. pp. 24-5.

6. $1900 . \quad, \quad$ Das Tierreich.

7. 1895. Rosa-Boll. Mus. Torino, x. No. 204. 


\section{$2 \mathrm{BHL}$ Biodiversity Heritage Library}

Friend, Rev Hilderic. 1916. "VI.-Alien Oligochaets in England." Journal of the Royal Microscopical Society 1916, 147-157. https://doi.org/10.1111/j.1365-2818.1916.tb00647.x.

View This Item Online: https://www.biodiversitylibrary.org/item/28010

DOI: https://doi.org/10.1111/j.1365-2818.1916.tb00647.x

Permalink: https://www.biodiversitylibrary.org/partpdf/71948

\section{Holding Institution}

MBLWHOI Library

\section{Sponsored by}

MBLWHOI Library

\section{Copyright \& Reuse}

Copyright Status: NOT_IN_COPYRIGHT

This document was created from content at the Biodiversity Heritage Library, the world's largest open access digital library for biodiversity literature and archives. Visit BHL at https://www.biodiversitylibrary.org. 